\title{
Poverty Determinants in Central Lombok District and the Countermeasures Effort: in Islamic Perspective
}

\author{
Rizkia Laila Ramdhani ${ }^{1}$
}

\begin{abstract}
This study discusses poverty determinants in Central Lombok Regency and its alleviation from Islamic Perspective. Methodologically, this study uses multiple linear regression with the Ordinary Least Squares (OLS) model and qualitative descriptive analysis. It uses secondary data obtained from the Central Statistics Agency (BPS), the National Development Planning Agency (BAPPENAS), and Regional Development Planning Agency (BAPPEDA). The result of this study shows that the population income affects the number of poor people. Therefore, the increased income of poor people to decrease poverty becomes policy recommendation in Islamic Perspective for related government in Central Lombok Regency.
\end{abstract}

Keywords: income, education, unemployment, Poverty Alleviation

\begin{abstract}
Abstrak. Penelitian ini membahas es penentu kemiskinan Kabupaten Lombok Tengah dan pengentasannya: dalam Perspektif Islam. Secara metodologis, penelitian ini menggunakan regresi linier berganda dengan model Ordinary Least Squares (OLS) dan analisis deskriptif kualitatif. Menggunakan data sekunder yang diperoleh dari Badan Pusat Statistik (BPS), Badan Perencanaan Pembangunan Nasional (BAPPENAS), dan Badan Perencanaan Pembangunan Daerah (BAPPEDA). Hasil penelitian ini menunjukkan bahwa jumlah pendapatan penduduk mempengaruhi jumlah penduduk miskin. Oleh karena itu, peningkatan pendapatan orang miskin untuk mengurangi kemiskinan menjadi rekomendasi kebijakan dalam Perspektif Islam untuk pemerintah terkait di Kabupaten Lombok Tengah.
\end{abstract}

Kata kunci: pendapatan, pendidikan, pengangguran, Pengentasan Kemiskinan

1Professional PT Permata Karya Lombok, Mataram | ramdhanirizkia@gmail.com 


\section{Introduction}

Poverty is a topic that is often discussed, both at the district, provincial, national, and even international levels. Poverty includes shortages in income and consumption, low education, poor health and nutrition, lack of access to various services, and dangerous environments (World Bank, 2018).

Poverty is one of the development priorities that the government continues to strive for in the 2015-2019 RPJMN. Poverty is a major problem in developing countries, where at different periods have different focuses (Bashir, 2018). Todaro and Smith (2012) also emphasized that poverty reduction is a core problem of all development problems as well as being the main objective of development policy. Besides, reducing the poverty level has also been a concern of Indonesia since the drafting of the 1945 Constitution. A low poverty rate is one manifestation of development planning, namely improving people's welfare.

The Companions of the Messenger of Allāh reported that the Messenger of Allāh requested the protection of Allah from poverty (Huda, 2015). As explained in the Hadith, which means, "O Allah, verily I take refuge in You from the slander of hellfire, and I protect You from the slander of wealth and also protect You from the libel of poverty" (Narrated by Abu Daud, Nasa 'i, and Ibn Majjah). In this Hadith, we can observe that poverty is a problem that must be addressed immediately and cannot be underestimated.

Determinants of poverty in Central Lombok Regency and according to Islamic perspectives have in common. First, poverty is caused by a lack of education (Zaman, 2018) and also skills (Ismail, 2012). According to BAPPEDA Central Lombok District (2017), the population aged 15 years and over according to education completed is 20.13 percent. Among them, they have not completed elementary, elementary and junior high school by 52.28 percent, high school graduates by 19.91 percent, and universities by 7.67 percent. The data means that the level of education completed by the 
population of productive age in Central Lombok Regency is still quite low because it still unable to meet the national education standard of 12 years of compulsory education. Second, poverty is caused by a lack of employment opportunities (Ali et al., 2016). The majority of Central Lombok Regency residents work as farmers, so they are still very dependent on agriculture (BAPPEDA, Central Lombok District, 2017), and 2.9 percent are unemployed (BPS, 2017). Third, low population income (Maipita, 2014) and uneven distribution will cause poverty (Ismail, 2012). The average income of the population of Central Lombok Regency from 2006-2017 continued to increase in the amount of 6,649,272 rupiahs to 12,415,115 rupiahs.

During the period 2006-2017, the percentage reduction in the number of poor people in Central Lombok has not reached the target of RPJMD 20162021 (BPS, 2017). The RPJMD is targeted to reduce poverty by $2 \%$ per year. It means that the government must take even more efforts to observe and review the policies and programs that will be made.

In terms of poverty reduction, Islam also has steps or strategies that can be used and applied to make policies in a region, even a country. According to Sadeq (1997), policies that can be implemented in poverty reduction according to Islam are increasing the income, equitable distribution of income, providing equal opportunities in accessing economic resources, obliging zakahpayment, and encourage charity activities. Aziz and Mohamad (2016) support Sadeq's opinion, that poverty alleviation schemes in Islam are by means of paying zakat, recommending charity, and state responsibility. Ismardi and Arisman (2015) assert that to overcome poverty is to work and try. Furthermore, according to Zaman (2018), reducing poverty is too narrow if it only focuses on money; it should look at the social, spiritual, and also improve capabilities through education.

\section{Method}

This research uses quantitative and qualitative methods. The quantitative method employs multiple linear regression analysis with 
Ordinary Least Squares (OLS) models, and the qualitative method use the descriptive qualitative analysis. The data used in this study are secondary data obtained from the national and regional Central Statistics Agency (BPS), the National Development Planning Agency (BAPPENAS), the West Nusa Tenggara Province Regional Development Planning Agency (BAPPEDA) and the Regional Development Planning Agency (BAPPEDA) Regency Central Lombok.

According to Gujarati and Porter (2009), multiple linear regression analysis is an analysis in which the dependent variable depends on two or more explanatory variables.

The general equation of multiple linear regression is as follows:

$Y i=\beta 1+\beta 2 X 2+\beta 3 X 3+\beta 4 X 4+\ldots+\beta n X n+$ ui $(1)$

Where:

$\begin{array}{ll}\mathrm{Yi} & : \text { Dependent variable } \\ \mathrm{B} & : \text { Parameters for variables } \\ \mathrm{X} 1, \mathrm{X} 2, \mathrm{X} 3, \ldots \mathrm{Xn} & : \text { Independent variable } \\ \mathrm{Ui} & \text { : stochastic disorders }\end{array}$

The function used in this study is as follows:

$\mathrm{POV}=\beta_{1}+\beta_{2} \mathrm{EDC}+\beta_{3} \mathrm{U}+\beta_{4} \mathrm{PDRBK}+\beta_{5} \mathrm{RFR}+\mathrm{u}_{\mathrm{i}}(2)$

Information:

$\begin{array}{ll}\text { POV }(\text { Poverty }) & =\text { Number of poor people } \\ \text { EDC }(\text { Education }) & =\text { Average length of school year } \\ \text { U }(\text { Unemployment }) & =\text { Unemployment rate } \\ \text { PDRBK } & =\text { PDRB per kapita } \\ \text { RFR (Regional Financial Ratio }) & =\text { Regional Financial Ratio }\end{array}$

The descriptive-qualitative data analysis strategy is also called quasiqualitative or quasi-qualitative design (Bungin, 2007). This analysis is influenced by quantitative traditions, especially in placing the theory on the data obtained. Descriptive qualitative emphasizes the descriptive, wherein the 
descriptive analysis is more analyzing the processes of occurrence of a phenomenon such as describing conditions, situations, and social reality. More clearly, in this study the qualitative method is used to analyze the implementation of policies in poverty reduction.

\section{Results and Discussions}

After analyzing the data, the following functions are obtained:

$\mathrm{POV}=25,13554+0,651745 \mathrm{EDC}+0,008726 \mathrm{U}-0,931843 \mathrm{PDRBK}+0,029402$ $\mathrm{RFR}+\mathrm{u}_{\mathrm{i}}(3)$

Based on the results of statistical tests, the education variable does not affect the number of poor people. The test results are not in accordance with the theory and previous research that underlies this study. The finding is supported by the data from BAPPEDA. As according to BAPPEDA, Central Lombok District (2017), education is very closely related to poverty. Improving education must be a development priority to overcome the problem of poverty. Furthermore, according to Chapra et al. (1997), education is critical to prospering the community. Todaro and Smith (2012) revealed that poverty is caused partly because of poor education. Supported by Zamroni (2015), Padda and Hameed (2016), Kasri (2017), Mohammed and Mugerwa (2017), Salami et al (2017), Listyaningsih (2018), Parveen and Cheema (2018), Ali andbrahim (2018) that low level of education will affect poverty. The high level of education will be able to make the population not dependent on the agricultural sector alone, have more ability to manage agriculture, and have skills to increase productivity.

Based on the results of statistical tests, the employment variable does not affect the number of poor people. According to the World Bank (2018), more jobs will be able to improve the welfare of the population. Opening job opportunities will be able to eradicate poverty (Chapra et al., 1997). Ali and Ibrahim's research (2018) found that lower employment opportunities make citizens have a higher chance of living in poverty. Mohammed and Mugerwa (2017) increasing job creation will reduce poverty. 
The population income variable has a significant and negative effect on the number of poor people. This means that if an increase in population income of 1 percent will be able to reduce the amount of poor people by 0.931843 percent. The results of the study are in accordance with the theories that previous studies used. According to Todaro and Smith (2012), the cause of poverty is low income. BAPPEDA Kabupaten Lombok Tengah (2017) states that the income of the population greatly influences poverty. When the population income is small or low, then the population will remain below the poverty line. So there needs to be an increase in population income in order to improve living standards.

Likewise, the finding is In line with research conducted by Zamroni (2015) in Central Lombok Regency, it is necessary to increase the income of residents of Central Lombok Regency. Seeing that the population of Central Lombok Regency still depends on the agricultural sector, it is necessary to increase income through the agricultural sector and also in the nonagricultural sector. Also emphasized by research conducted by Padda and Hameed (2016), Salami et al. (2017), Ali and Ibrahim (2018), and Listyaningsih (2018) revealed that low income is one of the factors causing poverty. Therefore, there needs to be an effort to increase income through community socio-economic development by increasing agricultural and non-agricultural outputs.

The regional financial ratio does not affect the number of poor people. The results of the study are not in accordance with existing theories, where the State or Government needs to focus on poor people by funding all the needs of the poor and investing in their welfare and future to overcome poverty (World Bank, 2018). In addition, government spending that focuses on the grassroots or the poor will be able to empower them to make the economy better (Huda et al., 2015). Zamroni's research results (2015) that the provision of subsidies to the poor population and providing transportation (Listyaningsih, 2018) will be able to reduce poverty in Central Lombok Regency. 
Thus, among the four variables tested in this study, the determinant of poverty in Central Lombok Regency is the population income.

\section{Local Government's Efforts in Reducing Poverty in Central Lombok District}

It is known that the determinant of poverty in Central Lombok Regency is population income. Therefore, the effort that must be optimized by the Central Lombok District Government to reduce poverty is to increase the income of the population. We have known that the majority of the poor come from the agricultural sector which is by 69.43 percent and the non-agricultural sector which is the industrial sector by 15.87 percent and the trade sector by 14.70 percent (BAPPEDA, Central Lombok District, 2017).

The following are several programs written in the Central Lombok District RPJMD in 2016-2021 to increase the income of the population through the agricultural and non-agricultural sectors:

Table 1.RPJMD Program in the Agriculture Sector (2016-2021)

\begin{tabular}{lll}
\hline \multicolumn{1}{c}{ PROGRAM } & \multicolumn{1}{c}{ STRATEGIES } \\
\hline $\begin{array}{l}\text { Agricultural / plantation extension } \\
\text { program }\end{array}$ & $-\begin{array}{l}\text { Providing education related to } \\
\text { Farmer welfare improvement program }\end{array}$ & - Fostering and training farmers to be \\
& more competent. \\
Agricultural / plantation production & - & Providing quality agricultural \\
improvement program & technology. \\
& $-\begin{array}{l}\text { Provide adequate agricultural } \\
\text { infrastructure. }\end{array}$ \\
& - Providing superior agricultural / \\
& plantation areas. \\
\hline
\end{tabular}

Author Resources

Tabel 2.RPJMD Program in the Non-Agriculture Sector (2016-2021)

\begin{tabular}{ll}
\hline Non-Agricultur Sector & \multicolumn{1}{c}{ Program } \\
\hline Trading & - Development of the number of MSMEs \\
& - Increased trade efficiency \\
& - Guiding street vendors \\
& - Economic empowerment of coastal communities \\
\hline Industry & - Women empowerment \\
& - Empowerment program for the poor and people with \\
& disabilities \\
\hline
\end{tabular}


- Empowerment of customary rural institutions

- Empowerment of the hand craftsmen

- Waste management

- Utilization of forest resources

Author Resources

The Role and Solution of Islam in Poverty Alleviation in Central Lombok District

It can be concluded from the previous discussion that the determinant of poverty in Central Lombok District is population income. So, Islam also has a solution in overcoming poverty through the agricultural and nonagricultural sectors.

According to research conducted by Fuadi (2016), that an interpreter of the Qur'an named Thanthawi Jauhari explains several verses of the Qur'an about agriculture in his work entitled Kitab Al-Jawahir fi Tafsir Al-Qur'an AlKarim, which is as follows:

First, different soil conditions. According to Qur'an Surah Yasin verses 33-35, Thanthawi Jauhari describe the meaning that several places that are suitable for planting plants. Date palms and bananas grow in hot and soft soil. Walnut trees, sprouts, nuts and the like grow on the ground the cold. Candlenut and bulb trees grow in the wild and desert. Reeds and shaf-shaf trees grow on the banks of rivers. In addition, an understanding of the types of plants and seeds really needs to be deepened.

Second, abandoned land productivity. According to Qur'an Surah Yasin verses 33-35, Thanthawi Jauhari describe the meaning that humans play a role in making the land more productive. Although plants and seeds can grow by themselves, the role of humans is needed to develop and care for them.

Third, soil higher than water surface. According to Qur'an Surah Yasin verses 33-35, Thanthawi Jauhari describe land that is higher than the water surface gets better results. Related to this, in agricultural science, it is explained that when the soil position is higher, the soil water content is low, so that the quality is getting better to achieve excellent agricultural yields. 
Therefore, high soil will absorb enough water compared to land that is in a low position (Fuadi, 2016)

Fourth, plant variations. In Al-Kahf verses 32-34, it is explained that good agriculture is when the land is overgrown with various plants, because if only one type of plant can cause damage to the soil. Regarding the agricultural system that has been explained in its interpretation, Thanthawi Jauhari gives an important emphasis that humans can bring blessings by means of faith and gratitude so that these blessings will bring abundant agricultural products (Fuadi, 2016).

Some ways that can be done to increase the productivity of farmers are input support, motivation, and training programs and extension services. This will have an impact on improving the ability of farmers about agricultural practices (Uddin et al., 2016).

In the research of Rahmah and Idris (2019), Caliph Umar bin Khattab made a policy of giving gifts to people working in the agricultural sector and also developing the abilities of workers. In addition, a fine is imposed on someone who intentionally damages a plant.

Research by Nurseha (2018) found that there are several policies made by Abu Yusuf regarding the agricultural sector, firstly in terms of taxation. Abu Yusuf approved the state to take part ef in the agricultural products of the cultivators, not from the vast land. This is intended to protect farmers who have less productive land. The second is about pricing. Abu Yusuf stressed that eheap low and high prices are not due to abundant or scarce production.

Fahlefi (2014) stated that in running his government, Umar bin Khattab developed economic principles in accordance with the Qur'an and Hadith, respecting and helping each other, and acting fairly. Caliph Umar utilized all factors of production, land, labor, and capital and avoided the occurrence of monopolies and oligopolies by carrying out direct supervision of the market to control prices.

The Non-agricultural sector consists of the industrial and trade sectors. To increase the income of the population through the industrial sector, the 
government must facilitate a place to make production and provide counseling to local communities (Permadi et al., 2017). It is widely known that Central Lombok that Central Lombok Regency is a region that produces handicraft industries such as rattan handicrafts made into bags, fruit baskets, etc., there are iron handicrafts made into knives, axes, machetes, etc., and also fabric crafts songket. As for the solution in the trade sector, especially MSMEs, the government makes a socialization program on Islamic microfinance to the public and provides training on business and technology (Suriadi, 2018).

Marketing strategies that can be carried out by the government to market domestic products are by developing the ability of local businesses to enter the international economy, paying attention to consumer behavior in ASEAN countries, facilitating capital loans, and expanding official financial services (Yhosino et al., 2016).

\section{Conclusion}

Determinants of poverty in Central Lombok Regency are population income. It has a negative and significant effect on poverty in Central Lombok Regency with a coefficient value of -0.931843 . That is, the increase in population income of 1 percent will be able to reduce poverty by 0.931843 percent.

The efforts of the Regional Government in overcoming poverty in Central Lombok Regency by increasing population income through two sectors namely agriculture and non-agriculture. The agricultural sector such as agricultural and plantation extension programs, improving farmers' welfare, and increasing agricultural and plantation production. While the non-agricultural sector such as development, empowerment and counseling in the industrial and trade sector.

The role and solution of Islam in overcoming poverty in Central Lombok Regency, namely by increasing the income of the population through the agricultural and non-agricultural sectors. As for the agricultural sector such as how to cultivate land, increase farmer productivity, and agricultural 
market policies. While the non-agricultural sector is facilitating production sites, providing counseling, providing socialization on Islamic microfinance, providing business and technology training, developing local business capabilities to enter the international economy, paying attention to consumer behavior in ASEAN countries, facilitating capital loans, and expanding services official finance.

\section{References}

Ali, A. F., \& Ibrahim, M. F. (2018). Determinant of Poverty among The Poor and Needy in A Developing Country. Journal of Emerging Economies $\mathcal{E}$ Islamic Research, Vol 6(2): 47-61.

Ali, I., Hatta, Z. A., Azman, A., \& Islam, S. (2016). Microfinance as a Development and Poverty Alleviation Tool and Rural Bangladesh: A Critical Assessment. Asian Social Work and Policy Review, Vol 11(1): 112.

Aziz, M. N., \& Mohamad, O. b. (2016). Islamic Social Business to Alleviate Poverty and Social Inequality. Social Economics, Vol 43(6): 573-592.

Badan Perencanaan Pembangunan Daerah Kabupaten Lombok Tengah \& Badan Pusat StatistikKabupaten Lombok Tengah. (2017). Analisis Tingkat Kemiskinan dan Karakteristik Penduduk Miskin Kabupaten Lombok Tengah Tahun 2016. Praya: BPS Kabupaten Lombok Tengah.

Badan Pusat Statistik Kabupaten Lombok Tengah. (2017). Kabupaten Lombok Tengah dalam Angka 2017. Praya: BPS Kabupaten Lombok Tengah.

Badan Pusat Statistik Provinsi Nusa Tenggara Barat. (2016). Provinsi Nusa Tenggara Barat dalam Angka 2016. Mataram: BPS Nusa Tenggara Barat.

Bashir, A.-H. (2018). Reducing Poverty and Income Inequalities: Current Approaches and Islamic Perspective. Islamic Economic, Vol 31(1): 93104.

Bungin, P. D. (2007). Penelitian Kualitatif. Jakarta: Prenada Media Group.

Chapra, D. M. (2000). Islam dan Pembangunan Ekonomi. Jakarta: GemaInsani.

Chapra, D. M., Akhtar, A., Ibrahim, A., Ahmad, K., \& Sadr, A. H. (1997). Etika Ekonomi Politik Elemen-Elemen Strategis Pembangunan Masyarakat Islam. Surabaya: Risalah Gusti.

Fahlefi, R. (2014). Kebijakan Ekonomi Umar bin Khattab. Jurnal Ilmiah Syariah, Vol. 13(2).

Fuadi, M. A. (2016). Ayat-Ayat Pertanian dalam Al-Qur'an (Studi Analisis Terhadap Penafsiran Thanthawi Jauhari dalam Kitab Al-Jawahir fi Tafsir Al-Qur'an Al-Karim. Bachelor Thesis: UIN Walisongo. 
Gujarati, D. N., \& Porter, D. C. (2009). Basic Econometrics. New York: McGrawHill Companies.

Huda, N., Rifaldi, I., Alhifni, A., Hasan, S. S., Afrianti, S., \& Noer, T. F. (2015). Ekonomi Pembangunan Islam. Jakarta: Prenamedia Group.

Ismail, N. (2012). A Critical Study of IbnSina's Economics Ideas. Tesis.

Ismardi, M., \& Arisman. (2015). Telaah Fiqh Siyasah dan Patologi Sosial Terhadap Konsep Zero Kemiskinan dalam Lima Pilar Pembangunan Kabupaten Kampar. Hukum Islam, Vol. 15(1).

Kasri, R. A. (2017). Determinants of Poverty amongst Zakah Recipients in Indonesia: A Household Level Analysis. International Journal of Islamic Economics and Finance Studies, Vol. 3(3): 30-40.

Listyaningsih, U. (2018). Perspektif Spasial Penanggulangan Kemiskinan di Yogyakarta. Patrawidya: Seri Penerbitan Penelitian Sejarah dan Budaya 19 (1), 93-112.

Maipita, I. (2014). Mengukur Kemiskinan dan Distribusi Pendapatan. Yogyakarta: UPP STIM YKPN.

Mohammed, M., \& Mugerwa, E. B. (2017). Employment Creation and Poverty Reduction in Nigeria: A Case of Farmers' Cooperative Societies in Kano State, Nigeria. Journal of Humanities, Vol. 2(1): 177-186.

Nurseha, M. A. (2018). Abu Yusuf (Suatu Pemikiran Ekonomi). Jurnal Ilmu Ekonomi Islam, Vol. 1(2).

Padda, I. U., \& Hameed, A. (2016). Estimating Multidimensional Poverty Levels in Rural Pakistan: A Contribution to Sustainable Development Policies. Journal of Cleaner Production, Vol. 197(1): 435442.

Parveen, S., \& Cheema, A. R. (2018). The Rural Non-Farm Economy and Poverty Alleviation in Tehsil Sillanwali, District Sargodha. Journal of Natural and Social Sciences, Vol. 7(3).

Permadi, L. A., Widiana, H., HS, R., \& Muttaqillah. (2017). Strategi Pengembangan dan Pemasaran DesaWisataSukarara yang Terintegrasi di Kecamatan Jonggat Kabupaten Lombok Tengah. Jurnal Magister Manajemen. Vol. 6(2).

Rahmah, N., \& Idris, M. (2019). Masa Keemasan Keuangan Islam (Perspektif Sejarah). Jurnal Ekonomi Bisnis Syariah, Vol. 2(1).

Sadeq, A. H. (1997). Poverty Alleviation: an Islamic Perspective. Humanomics, Vol. 13(3): 110-134.

Salami, M. F., Babatunde, R. O., Ayinde, O. E., \& Adeoti, E. I. (2017). Determinants of Poverty among Local Rice Processors in Kwara State, Nigeria. Journal of Sciences, Vol. 15(4): 386-391. 
Suriadi, I. (2018). Peluang dan Tantangan Lembaga Keuangan Mikro Syariah (BMT) dalam Mengurangi Kemiskinan di Nusa Tenggara Barat. Ekonobis, Vol. 4(1): 1412-7601.

Todaro, M. P., \& Smith, S. C. (2012). Economic development (11th ed.). Harlow: Pearson Education Limited.

Uddin, M. T., Dhar, A. R., \& Islam, M. M. (2016). Adoption of Conservation Agriculture Practice in Bangladesh: Impact on Crop Profitability and Productivity. Journal of The Bangladesh Agricultural University, Vol. 14(1): 101-112.

Zaman, A. (2018). An Islamic Approach to Inequality and Poverty. Islamic Economic, Vol. 31, (1): 69-92.

Zamroni, A. A. (2015). Analisis Tingkat PertumbuhanEkonomi, Kemiskinan, dan Ketimpangan di Kabupaten Lombok Tengah Tahun 2012. Thesis: Universitas Gadjah Mada 